\title{
Detection of Vibrio spp., Salmonella spp., and Shigella spp. among the frozen food samples employing enrichment culture technique
}

\author{
Tahmina Shammi* \\ Department of Microbiology, Stamford University Bangladesh, 51 Siddeswari Road, Dhaka 1217, \\ Bangladesh
}

Received 18 September 2015/Accepted 14 November 2015

\begin{abstract}
Freezing has long been an established method for food preservation. Freezing temperature may act as a stress factor for microbial cells, transforming the cells into injured or dormant state. Upon inoculation, these debilitated cells cannot grow on solid media and hence produce false negative results. Foods contaminated with injured cells of pathogenic bacterial strains are of potential health risk. Employing enrichment cultivation technique, present study attempted to detect such injured, dormant or viable but non culturable (VBNC) cells in different frozen food samples, collected from local markets and super-shops of Dhaka metropolis. Compared to the conventional cultivation means, the enrichment procedure revealed a significant increase in bacterial burden as well as increase in the pathogenic load. A maximum of $3 \log$ increase in case of total bacterial load while $4 \log , 5 \log$ and $2 \log$ increase in case of Vibrio spp., Salmonella spp. and Shigella spp., consecutively were observed. These findings clearly demonstrated the presence of injured cells in frozen foods which could be lethal under normal condition thereby posing public health risk.
\end{abstract}

Key words: Frozen food; Injured cells; Viable but non-culturable (VBNC) cells; Pathogenic microorganisms; Enrichment cultivation procedure; Public health

Foods are very much likely to be microbiologically contaminated during its production, packaging, transportation and storage (1-9). An array of microorganisms including enteric bacteria, Bacillus spp., Listeria monocytogenes, Yesinia enterocolitica, Pseudomonas spp., Clostridium perfringenes, Staphylococcus aureus, Campylobacter jejuni and vibrio spp. have been reported to be the common food spoilage bacteria $(1,3,4,8-11)$. An ever-enlarging world population has increased demands on frozen foods worldwide. Freezing has long been established as an excellent method of preserving high quality of foods $(7,10)$. However, due to high demand and popularity of frozen food, quality analysis of frozen food is receiving increased attention (7). The major consideration for recovery and isolation of microorganisms from frozen food could be the high proportion of sub-lethally injured cells; i.e., reversibly damaged or debilitated cells $(1,2,4,7,10)$. Injured microorganisms present a potential threat in food safety since they may repair themselves under suitable conditions $(2,3,6,7,12)$.

Storage at freezing temperatures is known to exert effects on microbiological loads of a variety of food products; due to its ability to lower metabolic activities $(6,7,13-17)$. Distribution and preparation prior to consumption of such products lead to the onset of several disease outbreaks (15-18). Bacterial pathogens

*Corresponding Author: Mailing address. Tahmina Shammi, Department of Microbiology, Stamford University Bangladesh, 51 Siddeswari Road, Dhaka 1217, Bangladesh, Bangladesh; E-mail: tahminashammi@yahoo.com. such as Escherichia coli, Salmonella spp., Shigella spp. and Vibrio species are well known for their etiological dominance in triggering enteric diseases in humans (1824). Therefore, the aptitude of progression as well as the continued existence of bacteria must be measured not only to detect the microbiological quality but also to assess the consumer safety of such stored frozen food products (2224).

To ensure a safe state of public health, there is a need for readily available methods to detect and enumerate bacterial pathogens in the commonly consumed foods $(8$, 24). A complication arises in this regard that most enteric pathogens appear intermittently and often in the viable but not non-culturable (VBNC) in the stored frozen foods. Thus, potentially pathogenic organisms present in a frozen food sample, may go undetected, largely due to their low numbers. The procedure of enrichment thus claims significance in order to avoid the possible false negative results (8). Along these lines, current study focused on recovery of the VBNC or injured cells (i.e., cells which can be enumerated after enrichment but not before that) among the common frozen food samples by employing the enrichment culture technique.

\section{MATERIALS AND METHODS}

Sampling, sample processing and enrichment of samples. Collection of samples was performed aseptically in the month of September 2014 from different places of New market, Malibag, Siddeswari and Mogbazar area in the Dhaka city of Bangladesh. Eight Samples of different categories including meat, fish, shrimp, squid, poultry and processed frozen foods (one chicken ball and one mutton roll) were collected and quickly transported to laboratory keeping in an ice box maintaining the temperature at $4{ }^{\circ} \mathrm{C}(25,26)$. Ten gm of each sample was weighed 
and added in a sterile homogenizing beaker containing $90 \mathrm{ml}$ of sterile normal saline, and then homogenized to prepare $100 \mathrm{ml}$ sample suspension for microbiological examinations.

As it is normally assumed that Salmonella spp., Shigella spp. and Vibrio spp. remain in viable but non-culturable (VBNC) state or in stressed condition in the environment $(24,27-29)$, therefore, enrichment technique was employed for the isolation and identification of these bacteria. One ml sample was added to $9 \mathrm{ml}$ selenite cysteine broth (SCB) (Difco Laboratories, Detroit, Mich.) and alkaline peptone water (APW) (Difco Laboratories, Detroit, Mich.), respectively. Culture suspensions were incubated for 4 hours at $37^{\circ} \mathrm{C}$ with shaking at 100 $\mathrm{rpm}$ (24). A series of 10 fold serial dilutions were made up to $10^{-6}$ for both nonenriched and enriched samples. Then $0.1 \mathrm{~mL}$ from each of the enriched broth was spread over Salmonella-Shigella agar (SSA) and Thioglycollate citrate bile salt (TCBS) agar respectively. Moreover, nutrient agar plates were also used for the determination of total viable bacteria and for the detection of psychrophiles by incubating the respective agar plates at $37^{\circ} \mathrm{C}$ for $12-24$ hours and at $2-7^{\circ} \mathrm{C}$ for 14 days (25).

Detection of Vibrio spp., Salmonella spp., and Shigella spp. Thiosulfate Citrate Bile Salt Sucrose (TCBS) (Difco Laboratories, Detroit, Mich.) agar plates were used to quantify the contaminating Vibrio spp. within the samples. While Salmonella-Shigella (SS) agar (Difco Laboratories, Detroit, Mich.) was used both for the isolation and quantification of Salmonella spp. and Shigella spp. After incubation at $37{ }^{\circ} \mathrm{C}$ for 24 hours, characteristic colonies were detected and enumerated $(9,11,24)$. Yellow colored colony on TCBS is characteristic of Vibrio spp. while the black centered colony on Salmonella/Shigella agar was considered as Salmonella spp. and the colorless colony on the same agar plates was noted as Shigella spp. A deduction of the pre-enriched bacterial load from the enriched ones detected the amount of injured cells of Vibrio spp., Salmonella spp., and Shigella spp. in all the samples examined. Finally, a series of biochemical tests were performed following the standard method to confirm the presence of these isolate

\section{RESULTS AND DISCUSSION}

Freezing is considered as one of the important tools for preserving materials of biological origins (30). Gram negative pathogens such as Salmonella and other Enterobacteriaceae are sensitive to freezing injury and there is also some mortality of mesophilic Vibrios (30). Various stress factors may lead to the generation of a dormant or viable but non-culturable state in the bacterial cells which direct bacteria to be unable to produce observable colonies when cultured on selective and non-selective agar media (31). Despite this condition, these bacteria possess the ability to cause disease in suitable conditions $(32,33,34)$. Previously a range of microorganisms have been isolated from various food items; however, investigation on the frozen foods by our group remained bared. Thus the present study attempted to examine the effect of enrichment technique in the recovery or the enhancement of the growth of microorganisms in different frozen food items in terms of total viable count as well as in the detection of various pathogenic organisms such as Vibrio spp., Salmonella spp. and Shigella spp.

In the present study, the total aerobic viable bacterial load ranged from $2.6 \times 10^{5}$ to $3.7 \times 10^{7} \mathrm{cfu} / \mathrm{g}$ (Table 1 ), observed in shrimp and chicken respectively. After enrichment an elevated count was found ranging from $2.9 \times 10^{7}$ to $5.6 \times 10^{9} \mathrm{cfu} / \mathrm{g}$ (Table 1 ). A maximum of $3 \mathrm{log}$ increase was noticed in beef and shrimp samples. Other samples also augmented at least 1 or $2 \log$. Hasan et al. (7) perceived TVC to be $2.6 \times 10^{5} \mathrm{cfu} / \mathrm{g}$ in frozen fish samples. Another study estimated TVC to be around $3.7 \times 10^{6} \mathrm{cfu} / \mathrm{g}$ without enrichment which is lower than this experiment. In the current study, we also attempted to observe the presence of psychrophilic bacteria in frozen food. Before enrichment 2 samples, chicken and shrimp showed presence of psychrophiles and after enrichment squid along with chicken and shrimp samples found to be positive. Maximum $3 \log$ increase was observed in squid, 1 log increase in chicken and shrimp remained unchanged after enrichment (Table 2). Psychrophiles were absent in other 5 samples. Psychrophilc organisms are not usually pathogenic but can cause spoilage of food products. Thus Psychrophilc load in frozen food has economic importance. Frozen fish can even be infected with this organism after coming in contact with ice made from Vibrio contaminated water $(33,35)$. In the present study, presence of Vibrio was found in all samples except rui fish and mutton roll. For the rest 6 samples, load of Vibrio spp ranged from $6.0 \times 10^{2}$ to $2.8 \times 10^{4} \mathrm{cfu} / \mathrm{g}$ (Table $1 \& 3$ ). After 4 hours of enrichment all the samples except the mutton roll showed an elevated count, with a maximum of $4 \log$ increase in growth was observed in rui fish (Table 1). (According to Massachusetts Department of Public Health, 1959 (36) Total viable bacteria should be $5.0 \times 10^{4}$ cfu/g, coliform should be $10 \mathrm{cfu} / \mathrm{g}$ and Staphylococcus spp., Salmonella spp., Shigella spp. and Vibrio spp. should be absent per gram of frozen pre-cooked food.

Several outbreaks of human disease both in developed and developing countries have occurred by Salmonella spp. (37). In our study, samples were of animal origin. Salmonella spp. were found to be absent before enrichment. But interestingly, after enrichment 5 samples showed high load of Salmonella spp. ranging from $2.3 \times 10^{2}$ to $1.6 \times 10^{5} \mathrm{cfu} / \mathrm{g}$ where squid sample harbored the highest load (Table $1 \& 3$ ). Hasan et al. (7), also observed Salmonella spp. in different frozen fish sample following enrichment technique within the margin of $1.6 \times 10^{5}$ to $1.3 \times 10^{6} \mathrm{cfu} / \mathrm{g}$. High load of Salmonella spp. has also been detected in several milk and milk products (38). In the current study, Shigella spp. was found to be present in all samples before and after enrichment within the range of $1.8 \times 10^{2}$ to $3.6 \times 10^{4} \mathrm{cfu} / \mathrm{g}$ and $4.0 \times 10^{4}$ to $1.0 \times 10^{5} \mathrm{cfu} / \mathrm{g}$, respectively (Table $1 \& 3$ ). A maximum two log increase was found in chicken ball and mutton roll while the other samples showed one log increase (Table 1).

\section{CONCLUSION}

An array of frozen foods contributes largely to the economy of Bangladesh, and it also serves as popular food items; therefore studies relating to disease onset, respective of storage, are required for the maintenance of national health and safety. Frozen meat, poultry especially shrimp which is a prime export product of Bangladesh have been studied previously. In our study, we attempted 
TABLE 1. Enumeration of total viable bacteria and pathogenic bacteria (Vibrio spp., Salmonella spp., and Shigella spp.) in frozen food samples

\begin{tabular}{ccccccccc}
\hline Sample & \multicolumn{2}{c}{ TAVB (cfu/g) } & \multicolumn{2}{c}{ Vibrio spp. (cfu/g) } & \multicolumn{2}{c}{ Salmonella spp. (cfu/g) } & \multicolumn{2}{c}{ Shigella spp. (cfu/g) } \\
\hline & Non enriched & Enriched & Non enriched & Enriched & Non enriched & Enriched & Non enriched & Enriched \\
\hline Chicken & $3.7 \times 10^{7}$ & $1.11 \times 0^{9}$ & $8.01 \times 0^{2}$ & $1.61 \times 0^{4}$ & 0 & $2.0 \times 10^{4}$ & $2.5 \times 10^{4}$ & $6.4 \times 10^{4}$ \\
Beef & $2.3 \times 10^{6}$ & $5.61 \times 0^{9}$ & $6.01 \times 0^{2}$ & $3.61 \times 0^{3}$ & 0 & 0 & $1.4 \times 10^{3}$ & $6.0 \times 10^{4}$ \\
Rui fish & $1.3 \times 10^{6}$ & $2.91 \times 0^{7}$ & 0 & $1.21 \times 0^{4}$ & 0 & $4.0 \times 10^{4}$ & $3.0 \times 10^{4}$ & $1.01 \times 10^{5}$ \\
Bele fish & $6.9 \times 10^{6}$ & $3.2 \times 10^{8}$ & $4.01 \times 0^{3}$ & $3.0 \times 10^{4}$ & 0 & 0 & $2.0 \times 10^{2}$ & $2.0 \times 10^{4}$ \\
Shrimp & $2.6 \times 10^{5}$ & $3.6 \times \times 10^{8}$ & $6.61 \times 0^{3}$ & $1.5 \times 10^{4}$ & 0 & $2.3 \times 10^{3}$ & $3.6 \times 10^{4}$ & $1.0 \times 10^{5}$ \\
Squid & $1.9 \times 10^{7}$ & $2.51 \times 0^{9}$ & $2.81 \times 0^{4}$ & $1.2 \times 10^{5}$ & 0 & $1.6 \times 10^{5}$ & $5.0 \times 10^{3}$ & $4.0 \times 10^{4}$ \\
Chicken ball & $3.8 \times 10^{6}$ & $6.01 \times 0^{8}$ & $6.01 \times 0^{2}$ & $6.8 \times 10^{3}$ & 0 & 0 & $1.8 \times 10^{2}$ & $5.0 \times 10^{4}$ \\
Mutton roll & $2.81 \times 0^{6}$ & $3.11 \times 0^{7}$ & 0 & 0 & 0 & $2.3 \times 10^{2}$ & $2.0 \times 10^{2}$ & $6.3 \times 10^{4}$ \\
\hline
\end{tabular}

TAVB $=$ Total aerobic viable bacteria

TABLE 2. Load of bacteria at refrigeration condition

\begin{tabular}{ccc}
\hline sample & \multicolumn{2}{c}{ TAVB $(\mathrm{cfu} / \mathrm{g})$} \\
\cline { 2 - 3 } & Non enriched & Enriched \\
\hline Chicken & $1.0 \times 10^{2}$ & $2.0 \times 10^{3}$ \\
Beef & 0 & 0 \\
Rui fish & 0 & 0 \\
Bele fish & 0 & 0 \\
Shrimp & $2.0 \times 10^{3}$ & $2.0 \times 10^{3}$ \\
Squid & 0 & $1.8 \times 10^{3}$ \\
Chicken ball & 0 & 0 \\
Mutton roll & 0 & 0 \\
\hline
\end{tabular}

TAVB $=$ Total aerobic viable bacteria

TABLE 3. Summery of biochemical identification of Vibrio spp., Salmonella spp., Shigella spp.

\begin{tabular}{|c|c|c|c|c|c|c|c|c|c|c|}
\hline \multirow{2}{*}{$\begin{array}{l}\text { Assumed } \\
\text { Organism }\end{array}$} & \multicolumn{3}{|c|}{ TSI } & \multirow{2}{*}{ 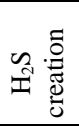 } & \multirow{2}{*}{ 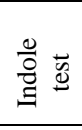 } & \multirow{2}{*}{$\cong \breve{s}$} & \multirow{2}{*}{$\begin{array}{l}\overrightarrow{0} \\
\stackrel{0}{0} \\
\stackrel{5}{>}\end{array}$} & \multirow{2}{*}{ 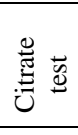 } & \multirow{2}{*}{ 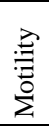 } & \multirow{2}{*}{ 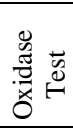 } \\
\hline & slant & Butt & gas & & & & & & & \\
\hline Vibrio spp & $\mathrm{Y}$ & $\mathrm{Y}$ & - & - & + & + & - & + & + & + \\
\hline Salmonella & $\mathrm{R}$ & $\mathrm{Y}$ & - & + & - & + & - & - & + & \\
\hline Shigella & $\mathrm{R}$ & $\mathrm{Y}$ & + & + & $+/-$ & + & - & - & - & \\
\hline
\end{tabular}

TSI = Triple Sugar Iron, $\mathrm{Y}=$ Yellow (Acid), R = Red (Alkaline), MR = Methyl red, VP =Voges-Proskauer

to detect microbiological quality as well as pathogenic load of different frozen foods, meat, poultry, shrimp with some processed frozen food and frozen squid which has recently been introduced to the urban consumer's of Bangladesh, Our study focused on enrichment is not suitable for enumeration rather a presence absence test, our future study may include establishment of quantitative method for injured cell analysis and risk assessment of different pathogens commonly observed in frozen food products. 


\section{ACKNOWLEDGEMENT}

This work was logistically supported and financed by Stamford University Bangladesh. Author is thankful to Dr. Rashed Noor, Chairman, Department of Microbiology, Stamford University Bangladesh for his invaluable supervision and thoughtful suggestions.

\section{REFERENCES}

1. Fraizer WC, Westhoff DC. 1995. Food Microbiology, $4^{\text {th }}$ ed. New Delhi.

2. Eze EI, Echezona BC, Uzodinma EC. 2011. Isolation and identification of pathogenic bacteria associated with frozen mackerel fish (Scomber scombrus) in a humid tropical environment. African Journal of Agricultural Research. 6 (7): 1918-1922.

3. Dinu LD, Bach S. 2011. Induction of viable but nonculturable Escherichia coli $\mathrm{O} 157: \mathrm{H} 7$ in the phyllosphere of lettuce: a food safety risk factor. Appl Environ Microbiol. 77 (23): 8295-302.

4. Jay JM, Loessner MJ, Golden DA. 2005. Modern food microbiology, $7^{\text {th }}$ ed. Springer Science, New York

5. Ye Q, Wu Q, Hu H, Zhang J, Huang H. 2015. Prevalence, antimicrobial resistance and genetic diversity of Yersinia enterocolitica isolated from retail frozen foods in China. FEMS Microbiol Lett; 362 (24). DOI: 10.1093/femsle/fnv197

6. Noor R, Hasan MF, Munna MS, Rahman MM. 2015. Demonstration of virulent genes within Listeria and Klebsiella isolates contaminating the export quality frozen shrimps. International Aquatic Research. 7 (2): 157 161

7. Noor R, Hasan MF, Rahman MM. 2014. Molecular characterization of the virulent microorganisms along with their drug-resistance traits associated with the export quality frozen shrimps in Bangladesh. SpringerPlus 3: 469.

8. Noor R, Feroz F. 2015. Requirements for microbiological quality management of the agricultural products: an introductory review in Bangladesh perspectives. Nutrition \& Food Science. 45 (5): 808-816.

9. Alam MS, Feroz F, Rahman H, Das KK, Noor R. 2015. Microbiological contamination sources of freshly cultivated vegetables. Nutrition \& Food Science. 45 (4): 646 - 658

10. Brown MH. 1991. Microbiological aspects of frozen foods. In: BALD WB (Ed.), Food Freezing: Today and tomorrow. Springer, London: Springer, p. $15-25$.

11. Feroz F, Senjuti JD, Noor R. 2013. Determination of microbial growth and survival in salad vegetables through in vitro challenge test. International Journal of Nutrition and Food Science. 2 (6): 312-319.

12. Dominguez SA, Schaffner DW. 2009. Survival of Salmonella in processed chicken products during frozen storage. J Food Prot. 72 (10): 2088-92.

13. Lindbäck T, Rottenberg ME, Roche SM, Rørvik LM. 2010. The ability to enter into an avirulent viable but non-culturable (VBNC) form is widespread among Listeria monocytogenes isolates from salmon, patients and environment. Vet Res. 41 (1): 8

14. Ro EY, Ko YM, Yoon KS. 2015. Survival of pathogenic enterohemorrhagic Escherichia coli (EHEC) and control with calcium oxide in frozen meat products. Food Microbiol. 49: 203-210.

15. Chaisowwong W, Kusumoto A, Hashimoto M, Harada T, Maklon K, Kawamoto K. 2012. Physiological characterization of Campylobacter jejuni under cold stresses conditions: its potential for public threat. J Vet Med Sci.74 (1): 43-50.

16. Alcaide E, Amaro C, Todoli R, Oltra R. 1999. Isolation and characterization of Vibrio parahaemolyticus causing infection in Iberian toothcarp Aphanius iberus. Diseases of Aquatic Organisms 35: 77-80.

17. Magajna B, Schraft H. 2015. Evaluation of Propidium Monoazide and Quantitative PCR To Quantify Viable Campylobacter jejuni Biofilm and Planktonic Cells in Log Phase and in a Viable but Nonculturable State. J Food Prot. 78 (7): 1303-11.
18. Besnard V, Federighi M, Declerq E, Jugiau F, Cappelier JM. 2002 Environmental and physico-chemical factors induce VBNC state in Listeric monocytogenes. Vet Res. 33 (4): 359-370.

19. Feng P, Weagant S, Grant M. 2002. Enumeration of Escherichia coli and the coliform bacteria. In: Bacteriological analytical manual, $8^{\text {th }}$ ed FAD/Center for Food Safety \& Applied Nutrition.

20. Oliveira SD, Santos LR, Schuch DM, Silva AB, Salle CT, Canal CW. 2002. Detection and identification of Salmonella from poultry-related samples by PCR. Vet. Microbiol. 87: 25-35.

21. Waturangi DE, Amadeus S, Kelvianto YE. 2015. Survival of enteroaggregative Escherichia coli and Vibrio cholerae in frozen and chilled foods. J Infect Dev Ctries. 9 (8): 837-43.

22. Tavoschi L, Severi E, Niskanen T, Boelaert F, Rizzi V, Liebana E, et al 2015. Food-borne diseases associated with frozen berries consumption: a historical perspective, European Union, 1983 to 2013. Euro Surveill. 20 (29): 21193.

23. Mody RK, Meyer S, Trees E, White PL, Nguyen T, Sowadsky R, et al. 2014. Outbreak of Salmonella enterica serotype I 4, 5,12:i:- infections: the challenges of hypothesis generation and microwave cooking. Epidemiol Infect. 142 (5): 1050-60.

24. Rahman F, Noor R. 2012. Prevalence of pathogenic bacteria in common salad vegetables of Dhaka Metropolis. Bangladesh Journal of Botany. 41 (2): 159-162.

25. Cappuccino JG, Sherman N. 1996. Microbiology - A laboratory manual The Benjamin/Cummings Publishing Co., Inc., Menlo Park, California.

26. American Public Health Association. 1998. Standard methods for the examination of water and wastewater, $20^{\text {th }}$ Ed. American Public Health Association, Washinton, D.C.

27. Colwell RR. 2000. Bacterial death revisited. In: Colwell RR, Grimes DJ (Ed.), Non-culturable micro-organisms in the environment. American Society of Microbiology, Washington D.C., USA, p. 325-342.

28. Oliver JD. 2005 The Viable but nonculturable state in bacteria. J. Microbiol. 43: $93-100$

29. Thushani W, Ariyawansa KWS, Arampath PC. 2003. Recovering ability of freeze-stressed Salmonella typhimurium and Staphylococcus aureus cells in frozen shrimp. Cey. J. Sci. 31: 61-67.

30. Cheng L, Sun DW, Zhu Z, Zhang Z. 2015. Emerging Techniques for Assisting and Accelerating Food Freezing Processes-A Review of Recent Research Progresses. Crit Rev Food Sci Nutr. 26 10.1080/10408398.2015.1004569

31. Özkancaa R, Saribiyikb F, Isika K, Sahina N, Kariptasc E, Flintd KP. 2009. Resuscitation and quantification of stressed Escherichia coli K12 NCTC8797 in water samples. Microbiol Res. 164: 212-222.

32. LeChevallier MW, McFeters GA. 1985. Interactions between heterotrophic plate count bacteria and coliform organisms. Appl. Environ. Microbiol. 49: $1338-1341$.

33. McFeters GA, Kippin JS, LeChevallier MW. 1986. Injured coliforms in drinking water. Appl. Environ. Microbiol. 51: 1-5.

34. Reissbrodt R, Rienaecker I, Romanova JM, Freestone PPE, Haigh RD, Lyte M, et al. 2002. Resuscitation of Salmonella enterica serovar Typhimurium and enterohemorrhagic Escherichia coli from the viable but nonculturable state by heat-stable enterobacterial autoinducer. Appl. Environ. Microbiol. 68: 4788-4794.

35. Kulawik P, Migdal W, Gambus F, Cieslik E, Özozul F, Tkaczewska J, et al. 2015. Microbiological and chemical safety concerns regarding frozen fillets obtained from Pangasius sutchi and Nile tilapia exported to European countries. J Sci Food Agric. DOI: 10.1002/jsfa.7233

36. Wang Y, Liu C, Zhang Z, Hu Y, Cao C, Wang X, et al. 2015. Distribution and Molecular Characterization of Salmonella enterica Hypermutators in Retail Food in China. J Food Prot. 78 (8): 1481-1487.

37. Hassan MR, Acharjee M, Das E, Das KK, Ahmed T, Akond MA, et al 2013. Microbiological study of sea fish samples collected from local markets in Dhaka city. International Food Research Journal. 20 (3): 1491-1495. 